\title{
Influence of aluminium and molybdenum on properties of coatings and cutting properties of coated tools
}

\author{
Marina Volosova $^{1, *}$, Jury Bublikov ${ }^{2}$, Catherine Sotova ${ }^{1}$, and Ilya Sadov ${ }^{1}$ \\ ${ }^{1}$ MSTU STANKIN, Vadkovsky per. 1, Moscow, 127994, Russia \\ ${ }^{2}$ IDTI RAS, Vadkovsky per. 18-1A, Moscow, 127055, Russia
}

\begin{abstract}
The paper presents the results of the investigation focused on the properties of the $\mathrm{Cr}, \mathrm{Mo}-(\mathrm{Cr}, \mathrm{Mo}) \mathrm{N}-(\mathrm{Cr}, \mathrm{Mo}, \mathrm{Al}) \mathrm{N}$ multilayered composite wear-resistant coating with a nanostructured wear-resistant layer. The nanostructure of the coating was investigated using transmission electron microscopy (TEM), the microhardness was measured, and the chemical composition was found. The cutting properties of a tool with the $\mathrm{Cr}, \mathrm{Mo}-(\mathrm{Cr}, \mathrm{Mo}) \mathrm{N}-(\mathrm{Cr}, \mathrm{Mo}, \mathrm{Al}) \mathrm{N}$ coating were studied during the turning of 09G2S silicon-manganese steel. It has been found that the use of a cutting tool with the $\mathrm{Cr}, \mathrm{Mo}-(\mathrm{Cr}, \mathrm{Mo}) \mathrm{N}-(\mathrm{Cr}, \mathrm{Mo}, \mathrm{Al}) \mathrm{N}$ coating reduces the flank wear rate by 1.65 times compared to an uncoated tool.
\end{abstract}

\section{Introduction}

At present, the most of the coatings widely used in industrial sphere are based on the TiN and $(\mathrm{Ti}, \mathrm{Al}) \mathrm{N}$ systems, as a rule, with the inclusion of additional elements, such as $\mathrm{Cr}, \mathrm{Mo}$, Y, Gf, Si, and others for the improvement of hardness, wear resistance, and heat resistance, which is very important [1-10]. Taking into account the fact that an enhancement of the cutting efficiency is an essential task of the modern manufacturing, while an increase in the cutting speed is a prevailing way to enhance the efficiency, the heat resistance is becoming an increasingly important property. The use of the coatings based on nitrides of such metals as $\mathrm{Cr}$ and Mo can provide not only high heat resistance of the coating, but also increased tribological properties of coated tools due to the formation of surface oxide films based on $\mathrm{MoO}_{3}$ and $\mathrm{Cr}_{2} \mathrm{O}_{3}$. In turn, the introduction of aluminium into the composition of the coatings further increase their hardness and wear resistance, as well as heat resistance and resistance to oxidation due to the formation of a protective film of $\mathrm{Al}_{2} \mathrm{O}_{3}$.

The properties of the $(\mathrm{Cr}, \mathrm{Mo}) \mathrm{N}$-based coatings are studied in a number of papers [1116]. It has been found that Mo atoms replace $\mathrm{Cr}$ atoms in the $\mathrm{CrN}$ system, while a substitutional solid solution is formed and the hardness and wear resistance increase [1114]. The wear resistance of the $(\mathrm{Cr}, \mathrm{Mo}) \mathrm{N}$ coating increases with a reduction in the nanolayer thickness [15]. The content of about 20 at $\% \mathrm{Al}$ in the $(\mathrm{Cr}, \mathrm{Mo}, \mathrm{Al}) \mathrm{N}$ coating provides the highest hardness and wear resistance in combination with a low coefficient of

* Corresponding author: dr.a.veres@yandex.ru 
friction [16]. At temperature of $900{ }^{\circ} \mathrm{C}$, the active formation of $\mathrm{MoO}_{3}, \mathrm{Cr}_{2} \mathrm{O}_{3}$, and $\mathrm{Al}_{2} \mathrm{O}_{3}$ oxides begins in the $(\mathrm{Cr}, \mathrm{Mo}, \mathrm{Al}) \mathrm{N}$ coating. With an increase in the $\mathrm{Al}$ content in the coating up to $50 \mathrm{at} \%$, its hardness grows to $41.2 \mathrm{GPa}$, while embrittlement also increases $[17,18]$. The results of the conducted studies prove that the nanolayer coatings which are based on nitrides of $\mathrm{Zr}, \mathrm{Nb}$, $\mathrm{Ti}$, and $\mathrm{Cr}$ and which include $\mathrm{Al}$, well combine high hardness and wear resistance with sufficient ductility and crack resistance while securing high heat resistance [19-28]. Tools with the specified coatings are characterized by good cutting properties during the turning and milling of materials of various machinability groups (steels of various compositions and titanium alloys).

The purpose of this paper was to study the properties of the $\mathrm{Cr}, \mathrm{Mo}-(\mathrm{Cr}, \mathrm{Mo}) \mathrm{N}$ $(\mathrm{Cr}, \mathrm{Mo}, \mathrm{Al}) \mathrm{N}$ multilayered composite coating with a nanostructured wear-resistant layer, as well as to investigate the cutting properties of the tool with the above coating during the turning of 09G2S silicon-manganese steel. Structural low-alloy 09G2S steel includes manganese and silicon as alloying elements. The hardness of 09G2S steel is HB 450-490 $\mathrm{MPa}$. A distinctive feature of 09G2S steel is its high level of durability life under cyclic load. Due to such advantage, 09G2S steel is widely used in construction, for the manufacturing of pipes, rolled metal products, and welded metal structures to be operated within the temperature range from -70 to $+425{ }^{\circ} \mathrm{C}$. The density of $09 \mathrm{G} 2 \mathrm{~S}$ steel is 7850 $\mathrm{kg} / \mathrm{m} 3$, and, accordingly, a fairly low weight of end products made of 09G2S steel has a great advantage over other heavier steels. 09G2S steel has a good ability to maintain its characteristics when operated under pressure within a wide temperature range. 09G2S steel is durable and resistant to loads with a variable force vector, and it also well undergoes heat treatment, which has a significant influence on its mechanical performance parameters.

\section{Materials and Methods}

The Cr,Mo-(Cr,Mo)N-(Cr,Mo,Al)N multilayered composite coating with a nanostructured wear-resistant layer was deposited through the VIT-2 unit [29-38] using the filtered cathodic vacuum arc deposition (FCVAD) technology [33-38] to minimize the number of microdroplets and secure the formation of a nanolayer structure with the nanolayer thickness of $0.5 \mathrm{~nm}$ and greater. A three-layer architecture of the coating was applied, including an adhesion layer of $\mathrm{Cr}, \mathrm{Mo}$, a transition layer of $(\mathrm{Cr}, \mathrm{Mo}) \mathrm{N}$, and a wear-resistant layer of $(\mathrm{Cr}, \mathrm{Mo}, \mathrm{Al}) \mathrm{N}[26]$.

During the deposition of the coatings, the cathodes of $\mathrm{Cr} 50$ at $\%+\mathrm{Mo} 50$ and $\mathrm{Al}$ $99,8 \mathrm{at} \%$, manufactured by powder metallurgy methods, were used.

During the turning of workpieces made of AISI 1045 steel, a CU 500 MRD lathe (SLIVEN) with a ZMM CU500MRD variable-speed drive was used. No coolants or lubricants were applied during the cutting process. Carbide inserts of SNUN ISO 1832:2012 were used as substrates, with the following parameters: $\gamma=-7^{\circ}, \alpha=7^{\circ}, \lambda=0, \mathrm{r}$ $=0.4 \mathrm{~mm}$; cutting mode: $\mathrm{f}=0.25 \mathrm{rpm}$, ap $=1.0 \mathrm{~mm}$, and $\mathrm{vc}=300 \mathrm{~m} / \mathrm{min}$. During the investigation of the wear dynamics on the carbide inserts, the operating time was assumed as 18 minutes to secure their stable operation until the beginning of catastrophic wear under the chosen cutting conditions.

You are free to use colour illustrations for the online version of the proceedings, but any print version will be printed in black and white unless special arrangements have been made with the conference organiser. Please check whether or not this is the case. If the print version will be black and white only, you should check your figure captions carefully and remove any reference to colour in the illustration and text. In addition, some colour figures will degrade or suffer loss of information when converted to black and white, and this should be considered when preparing them. 


\section{Results and Discussion}

The surface morphology of the Cr,Mo-(Cr,Mo)N-(Cr,Mo,Al)N coating and an example of an indentation mark during the microhardness measuring are exhibited in Fig. 1. The cluster structure of the coating is clearly visible with a mean cluster size of $2-5 \mu \mathrm{m}$. There are Mo microdroplets of 3-6 $\mu \mathrm{m}$ on the surface. The formation of such microdroplets occurs at the end of the coating deposition, and therefore, the microdroplets are registered mainly on the surface of the coating, while its internal structure contains almost no such microdroplets.

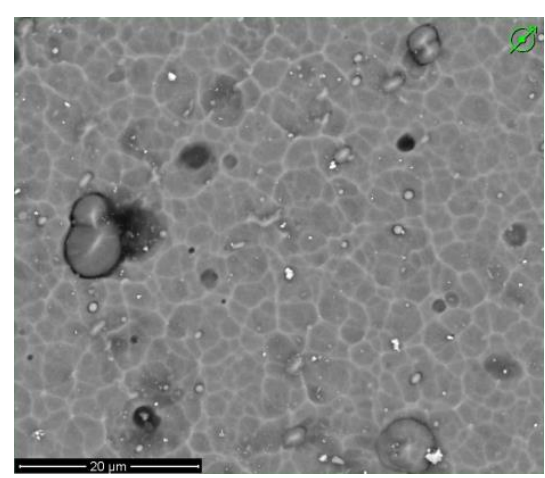

a

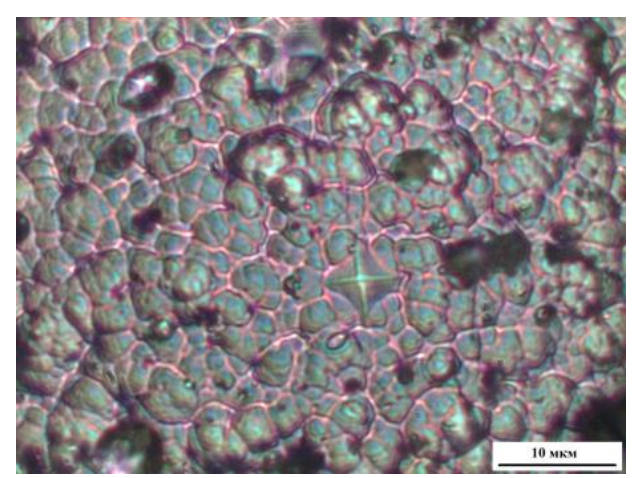

b

Fig. 1. (a) Surface morphology of the $\mathrm{Cr}, \mathrm{Mo}-(\mathrm{Cr}, \mathrm{Mo}) \mathrm{N}-(\mathrm{Cr}, \mathrm{Mo}, \mathrm{Al}) \mathrm{N}$ coating and (b) the indentation mark during the microhardness measuring.

The microhardness of the coating was measured at the lowest possible load of $10 \mathrm{~g}$ in order to avoid piercing of the coating (the indentation marks obtained with a load of less than $10 \mathrm{~g}$ are hardly noticeable), and 27 measurements were carried out to obtain sufficient accuracy of the results (see Fig. 1 b). The microhardness of the coating was $24.03 \pm 1.3$ GPa.

Fig. 2 presents the results of the study focused on the nanostructure of the Cr,Mo$(\mathrm{Cr}, \mathrm{Mo}) \mathrm{N}-(\mathrm{Cr}, \mathrm{Mo}, \mathrm{Al}) \mathrm{N}$ coating. The thickness of a $(\mathrm{Cr}, \mathrm{Mo}) \mathrm{N}$ transition layer was $850 \mathrm{~nm}$, while the thickness of a $(\mathrm{Cr}, \mathrm{Mo}, \mathrm{Al}) \mathrm{N}$ wear-resistant layer was $3680 \mathrm{~nm}$. In turn, the wearresistant layer has a nanolayer structure, and the nanolayer thickness is $92 \mathrm{~nm}$. Thus, the wear-resistant layer of the coating consists of 40 nanolayers. 


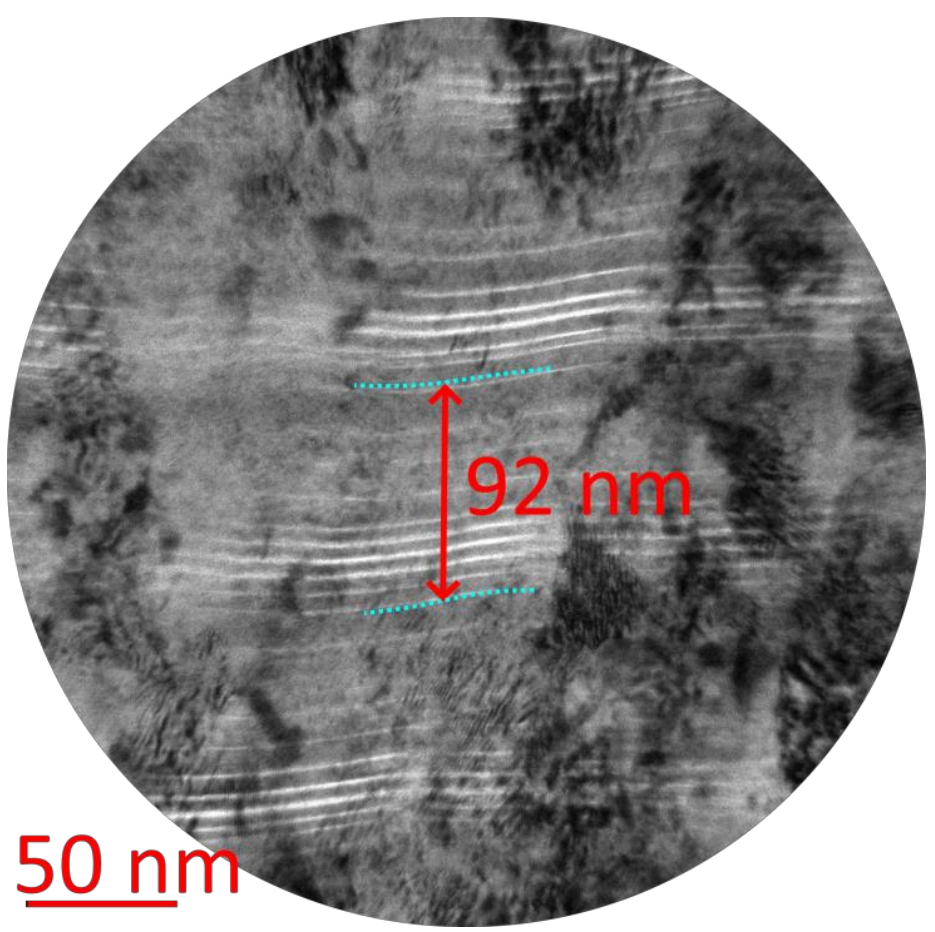

Fig. 2. Results of the study focused on the nanostructure of the $\mathrm{Cr}, \mathrm{Mo}-(\mathrm{Cr}, \mathrm{Mo}) \mathrm{N}-(\mathrm{Cr}, \mathrm{Mo}, \mathrm{Al}) \mathrm{N}$ coating.

The investigation of the chemical composition of the coating detected the content of about 70 at $\% \mathrm{Cr}, 20$ at $\% \mathrm{Mo}$, and 10 at $\% \mathrm{Al}$.

The cutting properties of the tool with the $\mathrm{Cr}, \mathrm{Mo}-(\mathrm{Cr}, \mathrm{Mo}) \mathrm{N}-(\mathrm{Cr}, \mathrm{Mo}, \mathrm{Al}) \mathrm{N}$ coating during the turning of 09G2S silicon-manganese steel were studied in comparison with the cutting properties of an uncoated tool (Fig. 3). The results of the experiments proved significantly higher wear resistance of tools with the $\mathrm{Cr}, \mathrm{Mo}-(\mathrm{Cr}, \mathrm{Mo}) \mathrm{N}-(\mathrm{Cr}, \mathrm{Mo}, \mathrm{Al}) \mathrm{N}$ coating $(\mathrm{VB}=0.305 \mathrm{~mm})$ compared to the wear resistance of the uncoated tool $(\mathrm{VB}=$ $0.505 \mathrm{~mm})$ after 18 minutes of cutting. While the uncoated tool has exceeded the limit of flank wear $\left(\mathrm{VB}_{\max }=0.4 \mathrm{~mm}\right)$, the tool with the $\mathrm{Cr}, \mathrm{Mo}-(\mathrm{Cr}, \mathrm{Mo}) \mathrm{N}-(\mathrm{Cr}, \mathrm{Mo}, \mathrm{Al}) \mathrm{N}$ coating retains its working efficiency. It can be noticed that as the cutting time increases, the difference between the flank wear rate for the tool with the $\mathrm{Cr}, \mathrm{Mo}-(\mathrm{Cr}, \mathrm{Mo}) \mathrm{N}-(\mathrm{Cr}, \mathrm{Mo}, \mathrm{Al}) \mathrm{N}$ coating and that for the uncoated tool increases. 


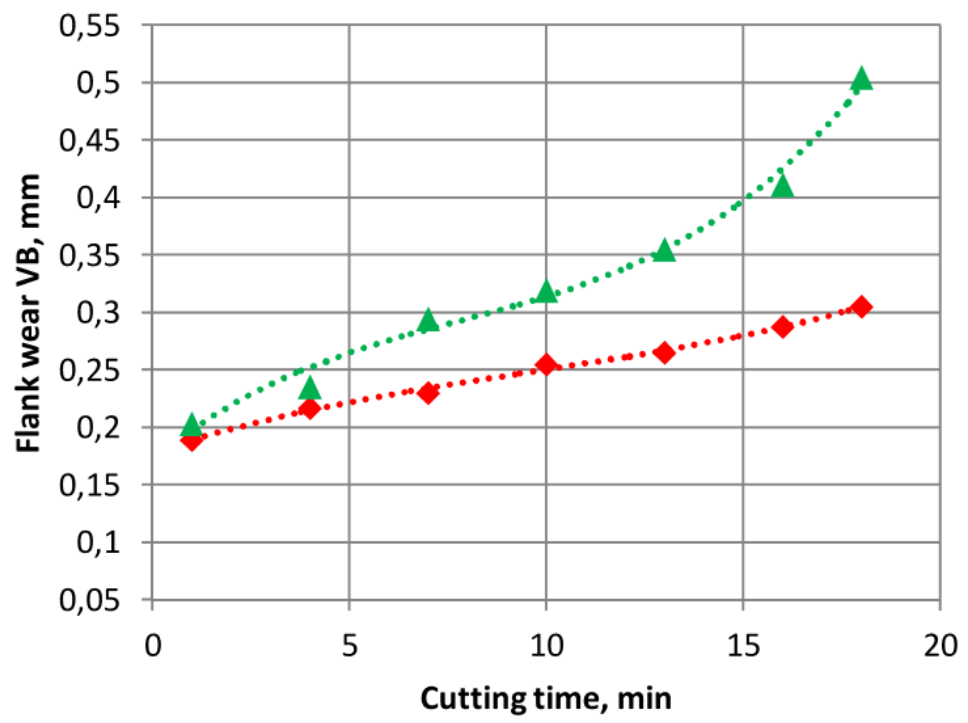

- $\mathrm{Cr}, \mathrm{Mo}-(\mathrm{Cr}, \mathrm{Mo}) \mathrm{N}-$ $(\mathrm{Cr}, \mathrm{Mo}, \mathrm{Al}) \mathrm{N}$

\section{$\Delta$ Uncoated}

Fig. 3. Relationship between the flank wear rate on the uncoated cutting inserts and the cutting inserts with the $\mathrm{Cr}, \mathrm{Mo}-(\mathrm{Cr}, \mathrm{Mo}) \mathrm{N}-(\mathrm{Cr}, \mathrm{Mo}, \mathrm{Al}) \mathrm{N}$ coating and the cutting time during the turning of $09 \mathrm{G} 2 \mathrm{~S}$ silicon-manganese steel.

The studies of the wear dynamics on the carbide insert with the $\mathrm{Cr}, \mathrm{Mo}-(\mathrm{Cr}, \mathrm{Mo}) \mathrm{N}$ $(\mathrm{Cr}, \mathrm{Mo}, \mathrm{Al}) \mathrm{N}$ coating during the turning of $09 \mathrm{G} 2 \mathrm{~S}$ steel are presented in Fig. 4 . There is a noticeable formation of a wear crater on the rake face and of the flank wear land. At the same time, after 18 minutes of cutting, the insert with the $\mathrm{Cr}, \mathrm{Mo}-(\mathrm{Cr}, \mathrm{Mo}) \mathrm{N}-(\mathrm{Cr}, \mathrm{Mo}, \mathrm{Al}) \mathrm{N}$ coating retains it cutting properties.

Rake face after $10 \mathrm{~min}$

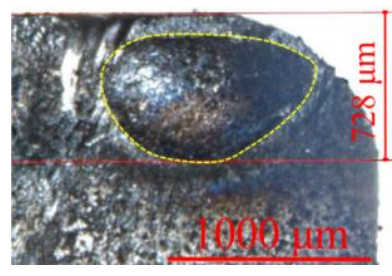

Rake face after $18 \mathrm{~min}$

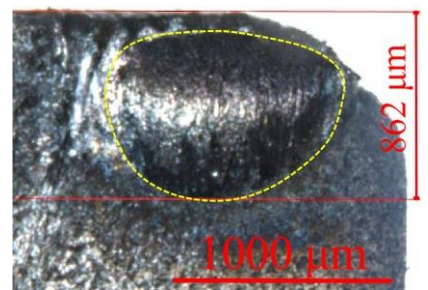

Flank face after $18 \mathrm{~min}$

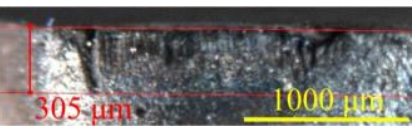

Fig. 4. Wear patterns on the contact pads of the carbide insert with the $\mathrm{Cr}, \mathrm{Mo}-(\mathrm{Cr}, \mathrm{Mo}) \mathrm{N}-$ $(\mathrm{Cr}, \mathrm{Mo}, \mathrm{Al}) \mathrm{N}$ coating: on the rake face after 10 and 18 minutes of operation and on the flank face after 18 minutes of operation.

\section{Conclusions}

The properties of the $\mathrm{Cr}, \mathrm{Mo}-(\mathrm{Cr}, \mathrm{Mo}) \mathrm{N}-(\mathrm{Cr}, \mathrm{Mo}, \mathrm{Al}) \mathrm{N}$ multilayered composite wear-resistant coating with a nanostructured wear-resistant layer were studied. The results of the studies have proved the following:

1. The coating structure includes a $(\mathrm{Cr}, \mathrm{Mo}) \mathrm{N}$ transition layer with the thickness of 850 $\mathrm{nm}$ and a $(\mathrm{Cr}, \mathrm{Mo}, \mathrm{Al}) \mathrm{N}$ wear-resistant layer with the thickness of $3680 \mathrm{~nm}$. The wearresistant layer has a nanolayer structure, consisting of 40 nanolayers with the nanolayer thickness of $92 \mathrm{~nm}$. 
2. The microhardness of the coating is $24.03 \pm 1.3 \mathrm{GPa}$.

3. The investigation of the chemical composition of the coating detected the content of about 70 at $\% \mathrm{Cr}, 20$ at $\% \mathrm{Mo}$, and 10 at $\% \mathrm{Al}$.

4. The cutting properties of the tools with the $\mathrm{Cr}, \mathrm{Mo}-(\mathrm{Cr}, \mathrm{Mo}) \mathrm{N}-(\mathrm{Cr}, \mathrm{Mo}, \mathrm{Al}) \mathrm{N}$ coating were studied during the turning of 09G2S silicon-manganese steel. It has been found that the use of the cutting tools with the $\mathrm{Cr}, \mathrm{Mo}-(\mathrm{Cr}, \mathrm{Mo}) \mathrm{N}-(\mathrm{Cr}, \mathrm{Mo}, \mathrm{Al}) \mathrm{N}$ coating reduces the flank wear rate by 1.65 times compared to the uncoated tools.

This work was funded by the state assignment of the Ministry of Science and Higher Education of the Russian Federation, project No. 0707-2020-0025

\section{References}

1. I. V. Blinkov, A. O. Volkhonskii, V. N. Anikin, E. A. Skryleva. Russ. Eng. Res. 32(11-12), 740 (2012)

2. H. Klostermann, F. Fietzke, R. Labitzke, T. Modes, O. Zywitzki. Surf. Coatings Technol. 204 (2009) 1076

3. A. Vereschaka, V. Tabakov, S. Grigoriev, N. Sitnikov, G. Oganyan, N. Andreev, F. Milovich, Wear 420-421, 17 (2019)

4. R.L. Boxman,V.N. Zhitomirsky, I. Grimberg, L. Rapoport, S. Goldsmith, B.Z. Weiss. Surf. Coatings Technol. 125, 257 (2000)

5. V.N. Zhitomirsky. Structure and properties of cathodic vacuum arc deposited NbN and NbN-based multi-component and multi-layer coatings. Surf. Coatings Technol. 201, 6122 (2007)

6. S. Zhang, D.J. Li, L. Dong, H.Q. Gu, R.X. Wan, Key Eng. Mater., 537, 307 (2013)

7. S. Zhang, N. Wang, D.J. Li , L. Dong, H.Q. Gu, R.X. Wan, X. Sun. Methods Phys. Res. B 307, 119 (2013)

8. V.M. Beresnev, S.S. Grankin, V.Y. Novikov, U.S.Nyemchenko, O.V. Sobol', P.V. Turbin. J. Nano- Electron. Phys. 6(4), 04011 (2014)

9. Y. Shi , F. Pan, M. Bao, H. Pan, Trans. Nonferrous Met. Soc. China 24, 2856 (2014)

10. Y. Shi ,F. Pan, M.Bao, Z. Yang, L. Wang. J. Alloys Compd. 559, 196 (2013)

11. K.H. Kim , E.Y. Choi , S.G. Hong, B. G. Park, J. H. Yoon, J.H. Yong. Surf. Coatings Technol. 201, 4068 (2006)

12. D. Qi, H. Lei, T. Wang, Z. Pei, J. Gong, C. Sun. J. Mater. Sci. Technol., 31(1), 55 (2015)

13. S.J. Heo ,S.-W. Kim, I.-W. Yeo, S.-J. Park, Y.-S. Oh., Ceram. Int. 42, 5231 (2016)

14. L. Zhou ,F.F. Klimashin, D. Holec , P.H. Mayrhofer. Scr. Mater. 123, 34 (2016)

15. B. Gu , J.P. Tu, X.H. Zheng, Y.Z. Yang, S.M. Peng. Surf. Coatings Technol. 202, $2189(2008)$

16. B. Lou, Y. Wang. Acta Metall Sin. 52(6), 727 (2016)

17. Y.-X. Wang, B.-Y. Lou, J. Pan, X. Zhang. T Nonferr Metal Soc. 27(7), 1403 (2017)

18. F.F. Klimashin, P.H. Mayrhofer. Scr. Mater. 140, 27 (2017)

19. V. Alexey, Key Eng. Mater. 581, 62 (2014)

20. V. Alexey, Adv Mat Res 712-715, 347 (2013)

21. A.S. Vereschaka, S.N. Grigoriev, V.P Tabakov, E.S. Sotova, A.A. Vereschaka, M.Yu. Kulikov, Key Eng. Mater. 581, 68 (2014) 
22. A.A. Vereschaka, S.N. Grigoriev, M.A. Volosova, A. Batako, A.S. Vereschaka, N.N. Sitnikov, A.E. Seleznev, Int. J. Adv. Manuf. Technol. 90(1-4), 27 (2017)

23. A.S. Vereshchaka, A.A. Vereshchaka, A.K. Kirillov, Key Eng. Mater. 496, 67 (2012)

24. A. Vereschaka, V. Tabakov, S. Grigoriev, N. Sitnikov, G. Oganyan, N. Andreev, F. Milovich, Wear 420-421, 17 (2019)

25. A. Vereschaka, S. Grigoriev, N. Sitnikov, F. Milovich, A. Aksenenko, N. Andreev. Int. J. Adv. Manuf. Technol. 102(9-12), 2953 (2019)

26. A.A. Vereschaka, V. Tabakov, S. Grigoriev, A. Aksenenko, N. Sitnikov, G. Oganyan, A. Seleznev, S. Shevchenko, Surf. Coatings Technol. 357, 218 (2019)

27. A. Vereschaka, A. Aksenenko, N. Sitnikov, M. Migranov, S. Shevchenko, C. Sotova, A. Batako, N. Andreev. Tribol. Int. 128, 313 (2018)

28. A. Vereschaka, V. Tabakov, S. Grigoriev, N. Sitnikov, N. Andreev, F. Milovich, Wear. 416-417, 72 (2018)

29. M.A. Volosova, S.N. Grigor'ev, V.V. Kuzin, Refract Ind Ceram 56, 91 (2015)

30. A. Metel, V. Bolbukov, M. Volosova, S. Grigoriev, Yu. Melnik. Instrum. Exp. Tech. 57(3), 345 (2014)

31. S.N. Grigoriev, O.V. Sobol, V.M. Beresnev, I.V. Serdyuk, A.D. Pogrebnyak, D.A. Kolesnikov, U.S. Nemchenko, J. Frict. Wear 35(5), 359 (2014)

32. O. V. Sobol', A. A. Andreev, S. N. Grigoriev, V.F. Gorban', M.A. Volosova, S.V. Aleshin, V.A. Stolbovoy, Probl. At. Sci. Technol. 4, 174 (2011)

33. V.V. Kuzin, S.N. Grigor'ev, M.A. Volosova, Refract. Ind. Ceram. 54, 376 (2014)

34. V.V. Kuzin, S.N. Grigoriev, M.Yu. Fedorov, J. Frict. Wear. 36(1), 40 (2015)

35. A.A. Vereschaka, S.N. Grigoriev, N.N. Sitnikov, G.V. Oganyan, A. Batako, Surf. Coat. Technol. 332, 198 (2017)

36. A.S. Metel, S.N. Grigoriev, Yu.A. Melnik, V.P. Bolbukov, Instrum. Exp. Tech. 55(1), 122 (2012)

37. A. Metel, V. Bolbukov, M. Volosova, S. Grigoriev, Y. Melnik, Surf. Coat. Technol 225, 34 (2013)

38. S. Grigoriev, Y. Melnik, A. Metel, Broad fast neutral molecule beam sources for industrial scale beam-assisted deposition. Surf. Coat. Technol. 156(1-3), 44 (2002) 